\title{
Inclusive democracy in coastal communities (political sociology study on the election of Perbekel 2019 in patas village, Buleleng district, bali)
}

\author{
I Gusti Made Arya Suta Wirawan ${ }^{1}$ I Wayan Mudana² \\ \{arthasuta@gmail.com¹, wayan.mudana@undiksha.ac.id ${ }^{2}$ \} \\ Universitas Pendidikan Ganesha, Indonesia ${ }^{12}$
}

\begin{abstract}
Inclusive develompment only can be manifested by the village head (called Perbekel in Balinese) who has inclusive vision on his political policy which implemented in all communities including coastal community. In recent years coastal community in Patas Village (Buleleng, Bali) need an inclusive development to bring welfare and prosperity for their own community by participating politcally in Village head Election (abbreviated as Pilkel) 2019. This coastal community only choose a candidate who promotes environmental quality improvement and women empowermet as their indicator to make a social economic improvement. Coastal community itself is a community who has bargaining power on this election caused $40 \%$ economic activities of Patas Village is supported by this community. Therefore, the election process carried out by all of the candidates was not only targeted at those who were politically literate or sensitive, but also mothers and young people from this community who were unfamiliar with politics. This is certainly interesting considering that so far coastal communities are often apathetic to politics and also to politicians. In the context of research that uses a qualitative approach by conducting observations and interviews, it is known that: 1) The village head election 2019 in Patas Village brings inclusive democracy habituation among the people in coastal community 2) Political awareness of coastal communities in Patas Village is formed and built through a number of participatory empowerment and community-based programs where the results of these activities have a very positive impact on improving socio-economic life for coastal communities.
\end{abstract}

Keywords: Inclusive democracy; Coastal Society; Perbekel Election.

\section{Introduction}

The different characteristics of the ecosystem from the community also influence the political conditions of the coastal community itself. Populist approaches to mainland communities often do not work considering the contrasting environment and limited access forces politicians to find ways to increase the political participation of coastal communities themselves. However, it is very rare for this alternative approach to be realized and eventually changes that are not as expected are felt again by the coastal community itself.

The coastal community in Patas Village tries to fix this. In the context of coastal development in North Bali, the coastal community in Patas Village often gets a share. The developments that are present are not only structural in nature which are often top down, but are 
included in philanthropic and community activities from the surrounding areas which are increasingly seen as getting better literacy and insight into coastal communities.

The selection of these two issues was motivated by the increasing political awareness of the coastal community towards their socio-economic conditions which was developed through the many empowerment programs from the government, universities and local communities that have the same target focus. The activities of planting coral reefs, cleaning the beach and sea, cultivating seaweed, and the participation of fishermen's wives in processing their catch have made significant changes to coastal communities. Environmental awareness, which is crucial for the sustainability of their economic life, has led the coastal communities of Patas Village, who mostly work as fishermen, to filter the vision and mission and programs of perbekel when they campaign.

In principle, the perbekel candidates also understand how they approach them. The community is now smarter in line with the more open and widespread information and education that can be obtained in a very easy, cheap and accessible way at any time. They also understand that the same approach to the different characters of society is a big mistake. However, perbekel candidates have understood that pre-campaign social capital and investment will greatly influence the outcome of the election itself. Now the coastal communities are more sensitive to politics and they are really making the village head election as a basis for changing their socioeconomic conditions. Inclusiveness must also really target the right category / issue considering that coastal communities are increasingly dynamic.

As predicted, not all village head candidates have a vision and mission that focuses on these three issues. The campaign only dwells on what the candidates develop basically because they believe that brotherhood is above all else. In fact, one of the candidates, I Kadek Sara Adnyana, S.Pd, in its flagship program, carried routine simakrama (friendship) with the community of each banjar as the main program. If we look at the use of the term friendship juxtaposed with simakrama, this certainly makes it even more clear that semiotically the candidate is campaigning for inclusiveness in his political program. Not only that, programs for mothers and protecting the environment (including waste management) were also important issues discussed during their campaign.

Historically, considering its location which is right in the coastal area, the majority of the community (including the coastal community) in Patas Village is relatively open and very easy to visit, especially by migrants. The identity mentality that is awakened is a cosmopolitan spirit that opens up to new things. Migration or population movement is not just physical movement but also involves the transfer of ideas and social attributes such as religion. Different religious identities do not make any distance. Family religion is proof of Kaimana as an encounter. There is no problem with embracing Islam, Christianity, or anything else. Family identity or kinship remains the unifier.

Without the migrants, Patas Village would never exist. Newcomers not only come to trade but also socialize, adapt and show various roles. This is where the diversity occurs, where each member of society who has acculturated and hybridized the area has become rich in cultural treasures. The coastal community, including those in Patas Village, as an area that is often untouched[1] by development, this area becomes the butt of political promises that lead to minimal implementation [1]. There are several reasons why coastal communities are often discriminated against politically. First, the locus of developmentalism in coastal villages is far from the city and its development often cannot be used as something monumental. Second, village developmentalism is politically insufficient to gain votes from politicians given the way of life of the people that is very different from those in mainland areas. Third, the developmentalism of coastal communities often has rather complicated requirements, especially those related to the environment. Fourth, coastal communities have strong traditions so that 
sometimes politicians have difficulty convincing potential voters. Fifth, as is often the case, coastal communities have been critical of political promises, so they are very selective in determining the candidates they will choose.

\section{Method}

This study used a descriptive qualitative research method located in the village of Patas. Methods of collection using observation techniques, interviews, document study. The data analysis techniques used are data reduction, data presentation and conclusion drawing. Checking the validity of the data is by means of triangulation of techniques and triangulation of sources.

\section{Results and Discussion}

\section{General description of Patas Village}

Patas Village is one of the villages in Gerokgak District, Buleleng Regency. As for the distance from Patas Village to the capital of the District, Regency and Provention. Patas Village has several hamlets consisting of Tegal Sari Hamlet, Tegal Asri Hamlet, Merta Sari Hamlet, Mekar Sari Hamlet, Yehpanes Hamlet, Yehbiyu Kaje Hamlet, and Yehbiyu Kelod Hamlet. Of the very large population of 11,009 people, in Patas Village there is also a population from the educational level.

It is no different from other coastal communities which geographically, the coastal community of Patas Village grows and develops in a coastal area, which is a transitional area between land and sea areas, and sociologically has different social characteristics from other communities, due to differences in the characteristics of the resources they have. Economically, the welfare of coastal communities is very dependent on marine products in the form of fisheries and aquaculture [1], which up to now is still open access, so that the environmental conditions of the coastal and marine areas determine the sustainability of their socio-economic conditions $[2]$.

Talking about coastal communities, it is almost certain that the issue that always arises is that people are marginalized, poor and become targets of exploitation by the rulers both economically and politically [2]. Poverty which has always been a trade mark for fishermen in several ways can be justified by several facts such as slum settlement conditions, low levels of income and education, their vulnerability to social, political and economic changes that hit, and their powerlessness against investor intervention., and the ruler who came. Besides that, their poverty is also caused by the problem of damage to the coastal-marine ecosystem which has a serious impact on the depletion of fishery resources.

Another problem that is no less important in fishermen's economic activities, especially related to coastal operations is the problem of business capital to provide all the needs for coastal activities, such as fuel for boats, coastal gear and so on. For coastal communities, especially small fishermen or traditional fishermen, the need for business capital, which can be accessed or used at any time [3].

This condition is a response to the large investment costs in the capture fisheries sector, while the income is uncertain and the level of income varies. With household consumption needs that must be met every day, fishermen do not have sufficient savings in funds if one day they have to deal with the fact that the coastal infrastructure they use is damaged and requires considerable repair costs. This limitation of ownership of cash funds then encourages fishermen 
to become trapped in a complex network of debt and receivables, especially to loan sharks or informal credit providers.

Apart from socio-economic problems, the environmental conditions of the coastal areas and the eye system fishermen's livelihoods also have an impact on educational and socio-religious issues, especially the religious education of the community. The livelihood system of coastal communities, which requires them to be in the middle of the sea for a long period of time, forces them to leave other activities besides 'coastal', including educational and socio-religious activities.

Fishermen usually take their children to go to sea, even though their children are schoolage children. As a result, of course, their education rights were not fulfilled to their full potential. Even only to meet the target of compulsory education for nine years, the government program. This is one of the arguments that underlie the low education of the coastal community. Likewise, in carrying out religious activities, they have very limited opportunities. As a result, their religious experience and religious education have become inadequate.

The population who only graduated from elementary school (SD) is quite a large number, namely 1,040 males and 1,107 females, the factors that cause this occur due to a lack of will to continue and inadequate economic factors so that they do not continue to the education level next. Of the population who graduated from Junior High School (SMP) with 662 males and 595 females, the population who graduated at the junior high school (SMP) level did not continue to the next level, this is because there is no will to continue. In addition, residents of the educational level who have not completed education,

There are people aged 18-56 who have attended elementary school (SD) but did not finish with 568 males and 475 females, there are also residents who did not continue their education or did not attend school from 18-56 years old with the number of males 315 people and 378 women, this happens because of economic factors that prevent them from completing elementary school (SD). The level of education in Patas Village varies widely with different numbers of men and women, which can be seen from the largest to the lowest. Education in general is very important for a better future.

Tabel 1. Patas Village Education Level (Source: Profil Desa Patas Tahun 2018)

\begin{tabular}{lcc}
\hline Education Level & Man & Woman \\
\hline 3-6 years old who have not entered kindergarten & 321 & 317 \\
\hline 3-6 years old who are in kindergarten / play group & 127 & 128 \\
\hline Age 7-18 years who never went to school & 207 & 238 \\
\hline Age 7-18 years who are currently in school & 1.270 & 1.188 \\
\hline Ages 18-56 never go to school & 315 & 378 \\
\hline $\begin{array}{l}\text { Ages 18-56 years old have never graduated from } \\
\text { elementary school }\end{array}$ & 568 & 475 \\
\hline $\begin{array}{l}\text { Graduated from elementary school / equivalent } \\
\text { The number of ages 18 - 56 years did not complete } \\
\text { junior high school }\end{array}$ & 1.040 & 1.107 \\
\hline $\begin{array}{l}\text { Number of ages 18 - 56 years did not complete } \\
\text { high school }\end{array}$ & 183 & 129 \\
\hline $\begin{array}{l}\text { Completed junior high school / equivalent } \\
\text { Graduated from high school / equivalent } \\
\text { Completed D-1 / equivalent }\end{array}$ & 146 & 125 \\
\hline
\end{tabular}




\begin{tabular}{lcc}
\hline Completed D-1 / equivalent & 17 & 10 \\
\hline Completed D-2 / equivalent & 19 & 11 \\
\hline Completed D-3 / equivalent & 33 & 19 \\
\hline Completed undergraduate degree / equivalent & 84 & 154 \\
\hline Completed S-2 / equivalent & 19 & 13 \\
\hline Completed S-3 / equivalent & 7 & 4 \\
\hline Graduated from SLB (Special School) A & 1 & 1 \\
\hline Completed SLB (Special School) B & 5 & 3 \\
\hline Graduated from SLB (Special School) C & 0 & 1 \\
\hline Total & 5.641 & 5.368
\end{tabular}

The total population reached 11,009 people divided by the type of work performed. As with the livelihoods of the population in Patas Village, with the largest number of people working as farmers with 1,251 male and 694 female farmers. In addition, there are also people who work as fishermen, with 125 men. As for the population in Patas Village, who from their livelihoods do not have a permanent job, with 341 men and 192 women. The livelihoods of the people in Patas Village are very diverse and have various types of work, from the largest to the smallest jobs as seen from the number of male and female residents.

\section{Inclusive Democracy in the Coastal Community of Patas Village}

In a democratic process, people have the space to be involved in various political processes or policy making. The process of community involvement in various political processes is called political participation. According to Samuel P. Huntington and Joan M. Nelson, political participation is to limit political participation as the activities of citizens acting as individuals, which are intended to influence decision-making by the government. Ordinary participation is individual or collective, organized or spontaneous, steady or sporadic, peaceful or violent, legal or illegal, effective or ineffective [4].

According to Almond [5], there are two kinds of political participation, namely conventional political participation and non-conventional political participation. Conventional political participation, which is a normal form of political participation in modern democracies, while conventional forms of political participation include; voting, political discussions, campaign activities, forming and joining interest groups, individual communication with political and administrative officials. Non-conventional political participation is a form of political participation that is not practiced in normal conditions, it can even take the form of illegal, violent and revolutionary activities. As for the forms of non-conventional participation, namely petitions, democracy, confrontation, strikes, acts of political violence against objects (destruction, bombings, arson), acts of political violence against humans (kidnapping, murder), guerrilla warfare and revolution.

Based on the results of observations and interviews with a number of informants, it can be concluded that the political awareness of the inclusion of coastal communities in Patas Village is motivated by a number of factors including:

1. The history of integration and solidity of the Hindu and Muslim communities in the village has been woven since hundreds of years ago, long before modern political structures entered the area. In other words, the relatively very strong integration and the relatively small escalation of conflict resulted in them being able to implement inclusiveness in any matter, 
including in political matters. Even so, many regions have experienced the opposite, namely politics and all forms of events that have split the community in a village, even this has continued after the election.

2. The merging of the concept of majority and minority. This happened because both parties made an equal and significant contribution to the progress of the village. This is also due to the fact that the socio-economic status of the people, both Hindu and Muslim, are in an equal state (equal), or in other words, neither of them is overly politically or economically to dominate one another.

3. The saturation of the client's patron political system. In this context those who tend to experience losses as a result of political events do not necessarily make them apathetic towards politics, on the contrary they become actors who oversee the conduct of the Perbekel elections. Coastal communities understand that basically politics is related to interests. However, the existing interests must be based on a rational program. After often experiencing misperceptions with political promises during the election period, now the coastal community has grown into a critical community and is very active in various political events [6].

The economic situation is so bad that labor fishermen are often forced to borrow money and goods for daily living needs from the skipper or businessman with the consequence that these labor fishermen become tied to the skipper or trader [7]. Patron-client relationships are not only limited to business relationships, but relationships are established that touch the personal problems of fishermen's households, such as: giving loans for child marriages, helping to pay off previous debts, paying school needs, and so on [7].

4. The desire to increase the role of women. This condition is crucial considering that in the context of coastal communities, women are economic supporters. In fact, not infrequently in certain conditions women (mothers) are the most dominant. The dual role and burden of women as caregivers actually causes low political participation [8]. The gender system in which the people of Patas Village implements a gender system through the division of tasks and workloads between men and women or in coastal coastal households, different tasks are assigned to husbands and wives. As for the results of the research, the task of male fishermen or husbands is in the "sea domain" while women or wives are in the "land domain".

Jobs at sea, such as carrying out coastal activities, are the domain of men because the characteristics of this job require strong physical abilities, speed of action, and high risk. With different physical abilities, women handle jobs on land, such as taking care of domestic responsibilities, as well as socio-cultural and economic activities. The involvement of fisherwomen in earning a living is not matched by the abilities and skills they possess so that empowerment is needed for coastal communities, especially fisherwomen so that they can improve their quality of life [9].

At least the involvement of fisherwomen in development in Patas Village has started to grow. In the 2019 village head elections nearly 80 percent of women were involved in the elections. This spirit arose because a number of Candidaat gave them a special approach and campaigned for their programs which were also specifically for the empowerment of women. However, most female voters do not openly support candidates and focus on programs that are considered realistic to be implemented in their communities. Even the women were accustomed to having empowerment activities, but some of the activities had no continuation of evaluation and assistance. So that in the end some of them felt that the activity was just a formality. However, the active enthusiasm of women in this village ultimately has a significant impact on the survival of the coastal community and this has further opened their horizons that they not only affect economic problems but also problems in the political field [10]. Therefore, perbekel candidates who has a vision of empowerment for women (mothers) will be considered as something that has the potential to be fully supported. 
5. Ecology has never been the target of the program. Many fishermen have actually complained about various damage to the sea which has resulted in a decrease in their catch [11]. In fact, a sustainable and well-preserved marine ecosystem can be an alternative for fishermen who also want to take a side job in the marine tourism sector [12]. Exploitation of Natural Resources In the context of exploitation of fishery resources, our coastal communities act out four behaviors as follows: (1) exploit fishery resources continuously without understanding the boundaries; (2) exploiting fishery resources, accompanied by destroying coastal and marine ecosystems, such as cutting down mangrove forests and taking coral reefs and sea sand; (3) exploiting fishery resources in destructive ways, such as coastal groups bombing fish, dissolving potassium cyanide, and operating nets that damage the environment, such as trawling or minitrawl; and (4) exploiting fishery resources combined with conservation measures, such as fishermen carrying out catches accompanied by policies to conserve coral reefs, mangrove forests, and operate environmentally friendly nets. The exploitative behavior above has broad implications for the scarcity of fishery resources and the poverty of fishermen. In addition, competition between labor fishermen for fisheries resources continues to increase, which has the potential to cause conflict, especially in water areas that are facing overcoastal conditions.

One of the experiences that became a lesson for the coastal community of Patas Village was when the Banjar Fishermen of the Yeh Biu Service, Patas Village, Gerokgak District together with Pelindo III Celukan Bawang and Kodim 1609 Buleleng carried out coral reef restoration efforts by sowing coral reef seeds in the coastal area of the village. in September 2019 a few months before the election.

The main assumption in ecology-politics leads to the stance that environmental change is not neutral in nature [12], but is a form of a politized environment that involves many interested actors at the local, regional, and global levels. The dominant actors are generally the state and the big private sector. This domination causes what is called a tragedy of enclosure, which is a tragedy due to state and private domination which causes public access to utilization and management to be increasingly restricted. This weakening of access makes society even more marginalized. The purpose of ecology-politics is not only an explanation of the phenomenon of environmental change, but also an important foothold in the formulation of environmental management policies.

Basically, the coastal communities are aware and they try not to be taken for granted for their social economic improvement. They do not want unsustainable political transactions. Therefore, the last three years they have been very selective about aid programs. The programs they receive seriously are assistance programs that will later make them more independent in building their socio-economic life. In other words, they prefer assistance in the form of education and everything related to development and environmental preservation rather than basic food assistance which they actually get automatically through internal village programs [13].

\section{Conclusion}

Based on the existing demographic data, it appears that the coastal community in Patas Village has quite an impact on the elactability of all candidates. It also appears that the number of students seems to be a significant political segment that the five prospective workers should look at. Of the three variables of Inclusive Democracy, the environmental variable (political ecology) is the one most raised to be the issue of village head election. With this conceptual spirit, political ecology takes a position, first: as its attention to 'scale', which allows prospective dealers to identify and analyze the chains that connect environmental dynamics with social, political, cultural and economic forces at various conceptual and physical sites, and second: its consequent focus on 'power' in its multiple manifestations as a central key to understanding how 
the notion of sustainability is created and disseminated. In realizing this, the coastal community realizes that the actor with the most capacity is the village head (Perbekel) they choose based on three major issues namely environment, plurality and women's empowerment. They realize that the weakening of these three areas makes society even more marginalized. The goal of an inclusive democracy that is envisioned by coastal communities is not only an explanation for the phenomenon of change in these three fields, but also an important foothold in the formulation of a welfare management policy that is integrated with the environmental ecosystem in which they live.

\section{References}

[1] M. Arsel, "Ekologi Politik Dimana Ekonominya?," J. Tanah Air, pp. 1-17, 2009.

[2] A. P. Tjilen, S. W. Ririhena, L. Antonio, and Y. E. Teturan, "The Coastal Community Development Project ( CCDP ) Environmentally Sustainable Empowerment Model in District Merauke The Coastal Community Development Project ( CCDP ) Environmentally Sustainable Empowerment Model in District Merauke," no. March 2019, 2018.

[3] B. Sulaiman, A. N. Bambang, H. Purnaweni, M. Lutfi, and E. M. A. Mohammed, "Jurnal Pendidikan IPA Indonesia COASTAL COMMUNITY PERCEPTION OF MANGROVES IN SULI," vol. 8, no. 4, pp. 561-569, 2019.

[4] J. R. Clark, "The Politics of Poverty and the Poverty of Politics," no. January 2006, 2015.

[5] T. Pavone, "Political Culture and Democratic Homeostasis: A Critical Review of Gabriel Almond and Sidney Verba' s The Civic Culture Tommaso Pavone ( tpavone@princeton.edu ), April 7 th , 2014 Synopsis Background on Structural Functionalism Almond and Verba ( 1963 ),”vol. 37, no. 3, pp. 1-5, 2014.

[6] J. Sulehan, N. Rahamah, and H. Abu, "Patron-Client Relationship of Urbanized Fishing Communities in Makassar," no. January, 2019.

[7] J. Scott, "Patron-Client Politics and Political Change in Southeast Asia," vol. 66, no. 1, pp. 91-113, 2009.

[8] W. T. Meetei, B. Saha, and P. Pal, "Participation of Women in Fisheries : A Study on Gender Issues in Manipur, India,” vol. 7, no. 4, pp. 905-913, 2016.

[9] F. Sobo, "WOMEN AND GENDER PARTICIPATION IN THE,” pp. 155-168.

[10] A. M. Pratiwi, A. Gina, and M. L. Villarosa-tanchuling, "The Presence and Power of Fisherwomen in the Villages of Morodemak and Purworejo: Against Violence, Bureaucracy \& a Biased Interpretation of Religion," vol. 22, no. 4, 2017.

[11] P. Olsson, V. Galaz, and W. J. Boonstra, "Sustainability transformations : a resilience perspective," vol. 19, no. 4, 2014.

[12] M. D. and E. O. McGinnis, "Social-ecological system framework : initial changes and continuing," Ecol. Soc., vol. 19, no. 2, pp. 1-12, 2014. 